1

\title{
Synthesis, characterization and electrochemical performance of
}

\author{
Al-substituted $\mathrm{Li}_{2} \mathrm{MnO}_{3}$ \\ Loraine Torres-Castro $^{\mathrm{a}}$, Jifi Shojan ${ }^{\mathrm{a}, \mathrm{b}}$, Christian M. Julien ${ }^{\mathrm{c}}$, Ashfia Huq ${ }^{\mathrm{d}}$, Chetan Dhital ${ }^{\mathrm{d}}$, \\ Mariappan Parans Paranthaman ${ }^{\mathrm{e}}$, Ram S. Katiyar ${ }^{\mathrm{a}, \mathrm{b}}$ and Ayyakkannu Manivannan ${ }^{\mathrm{f}}$ \\ ${ }^{a}$ Department of Physics and The Chemical Physics Graduate Program, University of Puerto \\ Rico, San Juan, PR 00931, USA \\ ${ }^{\mathrm{b}}$ Institute for Functional Nanomaterials, University of Puerto Rico, San Juan, PR 00931, USA \\ ${ }^{c}$ Physicochimie des Electrolytes, Colloïdes et Sciences Analytiques, Université Pierre et Marie \\ Curie-Paris-6 75005, Paris, France \\ ${ }^{\mathrm{d}}$ Chemical and Engineering Materials Division, Oak Ridge National Laboratory, Oak Ridge, TN \\ 37831, USA \\ ${ }^{\mathrm{e}}$ Chemical Sciences Division, Oak Ridge National Laboratory, Oak Ridge, TN 37831, USA \\ ${ }^{\mathrm{f}}$ United States Department of Energy, National Energy Technology Laboratory, Morgantown, \\ WV 26507, USA \\ *Corresponding author:
}

A. Manivannan

United States Department of Energy/ National Energy Technology Laboratory Energy Systems Dynamics Division 3610 Collins Ferry Rd.

P.O. Box 880

Morgantown, WV 26507-0880

manivana@netl.doe.gov

Tel: (304) 285-2078 


\begin{abstract}
$\underline{\text { Abstract }}$
$\mathrm{Li}_{2} \mathrm{MnO}_{3}$ is known to be electrochemically inactive due to $\mathrm{Mn}$ in tetravalent oxidation state. Several compositions such as $\mathrm{Li}_{2} \mathrm{MnO}_{3}, \quad \mathrm{Li}_{1.5} \mathrm{Al}_{0.17} \mathrm{MnO}_{3}, \quad \mathrm{Li}_{1.0} \mathrm{Al}_{0.33} \mathrm{MnO}_{3}$ and $\mathrm{Li}_{0.5} \mathrm{Al}_{0.5} \mathrm{MnO}_{3}$ were synthesized by a sol-gel Pechini method. All the samples were characterized with XRD, Raman, XPS, SEM, Tap density and BET analyzer. XRD patterns indicated the presence of monoclinic phase for pristine $\mathrm{Li}_{2} \mathrm{MnO}_{3}$ and mixed monoclinic/spinel phases $\left(\mathrm{Li}_{2-\mathrm{x}} \mathrm{Mn}_{1-\mathrm{y}} \mathrm{Al}_{\mathrm{x}+\mathrm{y}} \mathrm{O}_{3+\mathrm{z}}\right)$ for $\mathrm{Al}$-substituted $\mathrm{Li}_{2} \mathrm{MnO}_{3}$ compounds. The $\mathrm{Al}$ substitution seems to occur both at Li and Mn sites, which could explain the presence of spinel phase. XPS analysis for $\mathrm{Mn} 2 \mathrm{p}$ orbital reveals a significant decrease in binding energy for $\mathrm{Li}_{1.0} \mathrm{Al}_{0.33} \mathrm{MnO}_{3}$ and $\mathrm{Li}_{0.5} \mathrm{Al}_{0.5} \mathrm{MnO}_{3}$ compounds. Cyclic voltammetry, charge/discharge cycles and electrochemical impedance spectroscopy were also performed. A discharge capacity of $24 \mathrm{mAh} \mathrm{g}^{-1}$ for $\mathrm{Li}_{2} \mathrm{MnO}_{3}$, $68 \mathrm{mAh} \mathrm{g}^{-1}$ for $\mathrm{Li}_{1.5} \mathrm{Al}_{0.17} \mathrm{MnO}_{3}, 58 \mathrm{mAh} \mathrm{g}^{-1}$ for $\mathrm{Li}_{1.0} \mathrm{Al}_{0.33} \mathrm{MnO}_{3}$ and $74 \mathrm{mAh} \mathrm{g}^{-1}$ for $\mathrm{Li}_{0.5} \mathrm{Al}_{0.5} \mathrm{MnO}_{3}$ were obtained. Aluminum substitutions increased the formation of spinel phase which is responsible for cycling.
\end{abstract}

Keywords: lithium ion battery, energy storage, $\mathrm{Li}_{2} \mathrm{MnO}_{3}$ cathode, $\mathrm{Al}$ substitution 


\section{Introduction}

Lithium ion batteries have gained increased popularity among the scientific community due to their high energy density and long cycle life. Although, lithium-ion batteries are widely commercialized and are more popular for portable units such as cell phones and laptops, there are still limitations and needs improvement [1]. Many efforts have been made to search for new cathode materials that could potentially satisfy the market for high demand portable electronic devices and electric vehicle technology [2-4]. Among the cathode materials investigated, lithium manganese oxides have been exploited due to the abundance of $\mathrm{Mn}$ in earth, low toxicity and safety [5]. In this family of oxides, $\mathrm{LiMnO}_{2}$ and $\mathrm{LiMn}_{2} \mathrm{O}_{4}$ showed promising electrochemical properties, such as high discharge capacity and high operating voltage, respectively. However, these materials suffer from serious structural changes after certain number of cycles due to the presence of $\mathrm{Mn}^{3+}$ ion, which is known to be a Jahn-Teller active ion [6]. Side reactions such as $2 \mathrm{Mn}^{3+} \rightarrow \mathrm{Mn}^{4+}+\mathrm{Mn}^{2+}$, also lead to battery failure upon cycling, as $\mathrm{Mn}^{2+}$ is known to be soluble in non-aqueous electrolytes. $\mathrm{Li}_{2} \mathrm{MnO}_{3}$ belongs to the same family of oxide materials having a monoclinic structure with $\mathrm{C} 2 / \mathrm{m}$ space group symmetry. The $\mathrm{A}_{2} \mathrm{BO}_{3}$ rock-salt type configuration possesses a layered arrangement that can be represented as $\mathrm{Li}\left[\mathrm{Li}_{1 / 3} \mathrm{Mn}_{2 / 3}\right] \mathrm{O}_{2}$. In other words, in $\mathrm{Li}_{2} \mathrm{MnO}_{3}, 1 / 3$ of the Mn-ions in the transition-metal layer are replaced with Li ions. Layers of lithium ions and alternating layers of manganese ions are separated from one another by layers of cubic-close packed oxygen planes, thus resembling the ideal layered structure of $\mathrm{LiCoO}_{2}$ [7]. The existence of lithium in the transition metal layer provides a high theoretical capacity (460 
mAh $\mathrm{g}^{-1}$ ), which makes it a promising cathode material for $\mathrm{Li}$-ion batteries. $\mathrm{Li}_{2} \mathrm{MnO}_{3}$ has been widely studied due to its electrochemical activity in the high voltage region, i.e. $>4.5 \mathrm{~V}$ vs. $\mathrm{Li}^{0} / \mathrm{Li}^{+}$. Its electrochemical behavior has also been explored by a chemical delithiation process; however this compound has not been well characterized for lithium substitution [8].

The drawback of $\mathrm{Li}_{2} \mathrm{MnO}_{3}$ is the presence of $\mathrm{Mn}$ in +4 oxidation state, which makes the material electrochemically inactive. Despite, it can be made electrochemically active by extracting lithium and oxygen simultaneously from the structure by chemical or electrochemical means [8]. The activation of $\mathrm{Li}_{2} \mathrm{MnO}_{3}$ due to extraction of lithium along with oxygen by chemical treatments with $\mathrm{HNO}_{3}$ and $\mathrm{H}_{2} \mathrm{SO}_{4}$ has also been reported [9]. However, during the electrochemical reaction a phase transformation is observed where the new spinel structure is formed [9]. In addition, electrochemical activation has been achieved after exposing the electrode to potentials higher than $4.5 \mathrm{~V}$ vs. $\mathrm{Li}^{0} / \mathrm{Li}^{+}$, which causes the partial removal of lithium and oxygen from the structure [10]. In both cases, the activation process leads to the rearrangement of ions resulting in vacancies in the host structure, which allow the reversible intercalation of lithium.

Recently, researchers have been studying the effects of partially substituted manganese ions with other transition metals such as ruthenium, where a reversible capacity of $210 \mathrm{mAh} \mathrm{g}^{-1}$ was obtained by $40 \%$ substitution of manganese [11]. Mori et al. also investigated the effect of $\mathrm{Ru}$ doping in $\mathrm{Li}_{2} \mathrm{MnO}_{3}$, obtaining a discharge capacity of $192 \mathrm{mAh} \mathrm{g}^{-1}$ for $60 \%$ substitution of manganese, while at $80 \%$ the capacity was $\sim 180 \mathrm{mAh} \mathrm{g}^{-1}$. Ruthenium substitution studies demonstrated a noticeable improvement on the electrochemical performance of the cathode material due to the ability of ruthenium to be oxidized [12]. Kim et al. studied the effect of Al, 

these transition metals in the structure improved the electrochemical performance dramatically for the first discharge capacity (200-240 $\mathrm{mAh} \mathrm{g}^{-1}$ ) [13]. A different approach reported by Amalraj et al. was the synthesis of nanosized $\mathrm{Li}_{2} \mathrm{MnO}_{3}$ to decrease the particle size and increase the surface area, which lead to an increase in capacity of $75 \%\left(207 \mathrm{mAh} \mathrm{g}^{-1}\right)$ compared to the micron sized $\mathrm{Li}_{2} \mathrm{MnO}_{3}\left(28 \mathrm{mAh} \mathrm{g}^{-1}\right)$ [14]. The same research group performed a study about the relationship between cycling temperature and electrochemical behavior of the electrodes. They established that higher temperatures enhance the electrochemical performance as well as the cycle stability. In order to reduce the initial irreversible loss that $\mathrm{Li}_{2} \mathrm{MnO}_{3}$ is known for, Wang et al. coated the surface of the pristine material with $\mathrm{FePO}_{4}$, where an improve capacity and cycle stability was achieved [15]. Instead of substituting Mn site, Dong et al. studied Li site substitution with sodium to partially remove lithium. An improved capacity of $216 \mathrm{mAh} \mathrm{g}^{-1}$ for the initial cycle and $109 \mathrm{mAh} \mathrm{g}^{-1}$ for the $100^{\text {th }}$ cycle was reported [16].

In the present study, we investigated the electrochemical and structural properties of $\mathrm{Li}_{2} \mathrm{MnO}_{3}$ at room temperature by partially substituting $\mathrm{Li}$ with $\mathrm{Al}$ using the sol-gel Pechini method. The substitution in $\mathrm{Li}_{1.5} \mathrm{Al}_{0.17} \mathrm{MnO}_{3}, \mathrm{Li}_{1.0} \mathrm{Al}_{0.33} \mathrm{MnO}_{3}$ and $\mathrm{Li}_{0.5} \mathrm{Al}_{0.5} \mathrm{MnO}_{3}$ compounds is based on the charge balance state where $\mathrm{Al}$ has a +3 oxidation state compared to Li with +1 oxidation state. The effect of the Al ion substitution at the $\mathrm{Mn}$ and $\mathrm{Li}$ sites indicated improved structural and electrochemical behavior compared to the pristine $\mathrm{Li}_{2} \mathrm{MnO}_{3}$. 


\section{Experimental}

$\mathrm{Li}_{2} \mathrm{MnO}_{3}, \mathrm{Li}_{1.5} \mathrm{Al}_{0.17} \mathrm{MnO}_{3}, \mathrm{Li}_{1.0} \mathrm{Al}_{0.33} \mathrm{MnO}_{3}$ and $\mathrm{Li}_{0.5} \mathrm{Al}_{0.5} \mathrm{MnO}_{3}$ were synthesized using the sol-gel Pechini method [17]. For the individual compounds, synthesis was carried out using lithium nitrate $\left[\mathrm{LiNO}_{3}>98 \%\right.$; Luka], manganese nitrate $\left[\mathrm{Mn}\left(\mathrm{NO}_{3}\right)_{2} 50 \% \mathrm{w} / \mathrm{w}\right.$ aq. soln.; Alfa Aesar], aluminum nitrate nonahydrate $\left[\mathrm{Al}\left(\mathrm{NO}_{3}\right)_{3} \bullet 9 \mathrm{H}_{2} \mathrm{O} 98-102 \%\right.$; Alfa Aesar], ethylene glycol $\left[\mathrm{C}_{2} \mathrm{H}_{6} \mathrm{O}_{2}>99 \%\right.$; Alfa Aesar ] (EG) and citric acid $\left[\mathrm{H}_{3} \mathrm{C}_{6} \mathrm{H}_{5} \mathrm{O}_{7}>99.5 \%\right.$; Alfa Aesar $](\mathrm{CA})$ as the starting precursors materials. The molar ratio of M:EG:CA used was 1:1.2:1.2, where $\mathrm{M}$ is the sum of all metal ions. Stoichiometric ratios of the metals corresponding to each composition were measured and dissolved in deionized water along with $\mathrm{CA}$, which behaves as a chelating reagent. The solution was heated at $80{ }^{\circ} \mathrm{C}$ for 10 minutes before adding ethylene glycol to serve as the complex cross-linking reagent. As the water concentration decreased, the solution became a gel-like appearance. The beaker was transferred into a heating mantle kept at a temperature of $130{ }^{\circ} \mathrm{C}$ until all the $\mathrm{NO}_{\mathrm{x}}$ gases released to form a 3D-polymeric structure. The resulting dark grey color powder was placed in an oven at $130{ }^{\circ} \mathrm{C}$ for $24 \mathrm{~h}$ to complete the drying process. The final dried powder was annealed at $750{ }^{\circ} \mathrm{C}$ for $8 \mathrm{~h}$ in air to form the final compound which was bright orange in color.

The structural phase identification of the materials and the presence of any crystalline impurities in the compounds were studied with PANalytical X'Pert Powder diffractometer (XRD) using a $\mathrm{CuK}_{\alpha}$ radiation $(\lambda=1.54056 \AA)$. XRD spectra were acquired at $45 \mathrm{kV}$ and $40 \mathrm{~mA}$ for a $2 \theta$ ranging from $10-90^{\circ}$. Time of flight (TOF) neutron diffraction measurements were performed at POWGEN powder diffractometer at the Spallation Neutron Source (SNS), Oak 
Ridge National Laboratory. The data were collected with a central wavelength of $1.066 \dot{A}$ at both $300 \mathrm{~K}$ and $10 \mathrm{~K}$. This facility covers a d-spacing range of $0.276 \dot{\mathrm{A}}$ to $4.606 \dot{\mathrm{A}}$. Raman scattering (RS) spectra were recorded using a T6400 spectrometer equipped with a triple grating monochromator and a Coherent Innova 90C Ar laser at $514.5 \mathrm{~nm}$. The morphology of the samples was analyzed with a Scanning Electron Microscopy (SEM) conducted with JEOL 7600 FE-SEM interfaced with a Thermo-Electron S7 X-ray Microanalysis system. System was calibrated using $\mathrm{CuK}_{\alpha}=8.041 \mathrm{keV}$. The specific surface area was measured with the Brunauer, Emmett, and Teller (BET) method using an ASAP 2020, Micromeritics. Tap density analysis was performed with an Autotap Quantachrome instrument.

X-ray photoelectron spectroscopy (XPS) spectra were obtained utilizing a Physical Electronics (PE) SAM-590 UHV system equipped with a PE spherical capacitor type analyzer with an Omni Focus III Lens and a PE 04-303 Ar-ion Gun. Binding energies (BEs) were referenced to adventitious carbon at $284.8 \mathrm{eV}$ [18].

The electrochemical behavior of the as-synthesized materials was examined in a twoelectrode CR2032-type coin cell configuration using liquid electrolytes consisting of $1 \mathrm{~mol} \mathrm{~L}^{-1}$ $\mathrm{LiPF}_{6}$ dissolved in 1:2(v/v) mixture of ethylene carbonate (EC) and dimethyl carbonate (DMC). The working electrode was fabricated by mixing $80 \mathrm{wt} . \%$ of the active material, $10 \mathrm{wt}$ \% of polyvinylidene fluoride binder (PVDF, Alfa Aesar) and $10 \mathrm{wt} \%$ of carbon black (Alfa Aesar) [19]. The slurry was prepared using 1-methyl 2-pyrolidone as the solvent and was coated onto Al foil substrates to form a homogeneous electrode. Li metal foil was used as the counter electrode and Celgard 2400 was used as a separator between anode and cathode. The coin cell was assembled inside the Ar-filled glove box (MBraun, $\mathrm{O}_{2}$ and $\mathrm{H}_{2} \mathrm{O}<1 \mathrm{ppm}$ ). 
The electrochemical analysis of the coin cells was investigated with cyclic voltammetry (CV), charge/discharge process (C/D) and electrochemical impedance spectroscopy (EIS). Cyclic voltammetry was performed on the coin cells at a scan speed of $0.1 \mathrm{mV} \mathrm{s}^{-1}$ and a potential range of 2.0-4.8 V with a Solartron Analytical 1470E Cell Test station. The cells were tested using a constant current method (C/D) of $0.05 \mathrm{C}\left(10 \mathrm{~mA} \mathrm{~g}^{-1}\right)$ with a potential window ranging from 2.8-4.8 $\mathrm{V}$ on an Arbin 60 channels battery tester. The impedance was measured using the ac voltage of $5 \mathrm{mV}$ over a frequency range of $100 \mathrm{kHz}$ to $10 \mathrm{mHz}$ using a Solartron Analytical 1252A Frequency Response Analyzer.

\section{Results and discussion}

\subsection{X-ray Diffraction:}

Powder X-ray Diffraction patterns for $\mathrm{Li}_{2} \mathrm{MnO}_{3}, \mathrm{Li}_{1.5} \mathrm{Al}_{0.17} \mathrm{MnO}_{3}, \mathrm{Li}_{1.0} \mathrm{Al}_{0.33} \mathrm{MnO}_{3}$ and $\mathrm{Li}_{0.5} \mathrm{Al}_{0.5} \mathrm{MnO}_{3}$ compounds synthesized by a sol-gel Pechini method are shown in Fig. 1. The pristine $\mathrm{Li}_{2} \mathrm{MnO}_{3}$ diffraction pattern displayed no impurity peaks as demonstrated in Fig. 1a, matching with the PDF\# 84-1634. This confirms the presence of a single phase for $\mathrm{Li}_{2} \mathrm{MnO}_{3}$ with lattice parameters in agreement with the literature values [14, 20-22]. The XRD pattern for $\mathrm{Li}_{1.5} \mathrm{Al}_{0.17} \mathrm{MnO}_{3}$ (Fig. 1b) showed all the diffraction peaks similar to $\mathrm{Li}_{2} \mathrm{MnO}_{3}$. However, some of the peaks were split at the top, which represents a spinel phase in the structure. Fig. 1c presents the XRD profile for $\mathrm{Li}_{1.0} \mathrm{Al}_{0.33} \mathrm{MnO}_{3}$ compound, in which a spinel phase formation is revealed. Fig. 1d shows the XRD pattern for $\mathrm{Li}_{0.5} \mathrm{Al}_{0.5} \mathrm{MnO}_{3}$ compound where the intensities of the characteristic peaks $\left(2 \theta=20-23^{\circ}\right)$ of $\mathrm{C} 2 / \mathrm{m}$ group symmetry are weak. These characteristic peaks are due to the presence of lithium in the transition metal layers and, identified in the lattice 
with the Miller indices (hkl) of $(0,2,0)$ and $(1,1,0)$, in which only lithium and oxygen are present in the plane. The intensity of this peak seems to decrease as the amount of aluminum substitution is increased, which could be due to the simultaneous substitution of aluminum into the manganese and lithium sites or loss of lithium during synthesis. The diffraction peaks were fitted based on the monoclinic $\mathrm{Li}_{2} \mathrm{MnO}_{3}$ for which a Rietveld refinement was performed to obtain the lattice parameters listed in Table 1.

Table 1. Lattice parameters of $\mathrm{Li}_{2} \mathrm{MnO}_{3}, \mathrm{Li}_{1.5} \mathrm{Al}_{0.17} \mathrm{MnO}_{3}, \mathrm{Li}_{1.0} \mathrm{Al}_{0.33} \mathrm{MnO}_{3}$ and $\mathrm{Li}_{0.5} \mathrm{Al}_{0.5} \mathrm{MnO}_{3}$ based on the monoclinic structure. Lattice parameters for the $\mathrm{Al}$ substituted $\mathrm{Li}_{2} \mathrm{MnO}_{3}$ phases based on the spinel structure is reported in Table 2 .

\begin{tabular}{lllllll}
\hline Composition & $a(\AA)$ & $b(\AA)$ & $c(\AA)$ & $\beta\left(^{o}\right)$ & $V\left(A^{3}\right)$ & $X S(\mathrm{~nm})$ \\
\hline $\mathbf{L i}_{\mathbf{2}} \mathbf{M n O} \mathbf{O}_{\mathbf{3}}$ & 4.9086 & 8.4742 & 4.9988 & 108.95 & 196.66 & $49.6(2)$ \\
$\mathbf{L i}_{\mathbf{1 . 5}} \mathbf{A l}_{\mathbf{0 . 1 7}} \mathbf{M n O}_{\mathbf{3}}$ & 4.9811 & 8.5289 & 5.0034 & 108.95 & 201.00 & $21.2(2)$ \\
$\mathbf{L i}_{\mathbf{1 . 0}} \mathbf{A l}_{\mathbf{0 . 3 3}} \mathbf{M n O}_{\mathbf{3}}$ & 5.0356 & 8.5367 & 5.0231 & 110.9 & 201.70 & $31.2(1)$ \\
$\mathbf{L i}_{\mathbf{0 . 5}} \mathbf{A l}_{\mathbf{0 . 5}} \mathbf{M n O} \mathbf{M}_{\mathbf{3}}$ & 5.0442 & 8.5383 & 5.9625 & 111.3 & 239.30 & $47.6(1)$ \\
\hline
\end{tabular}




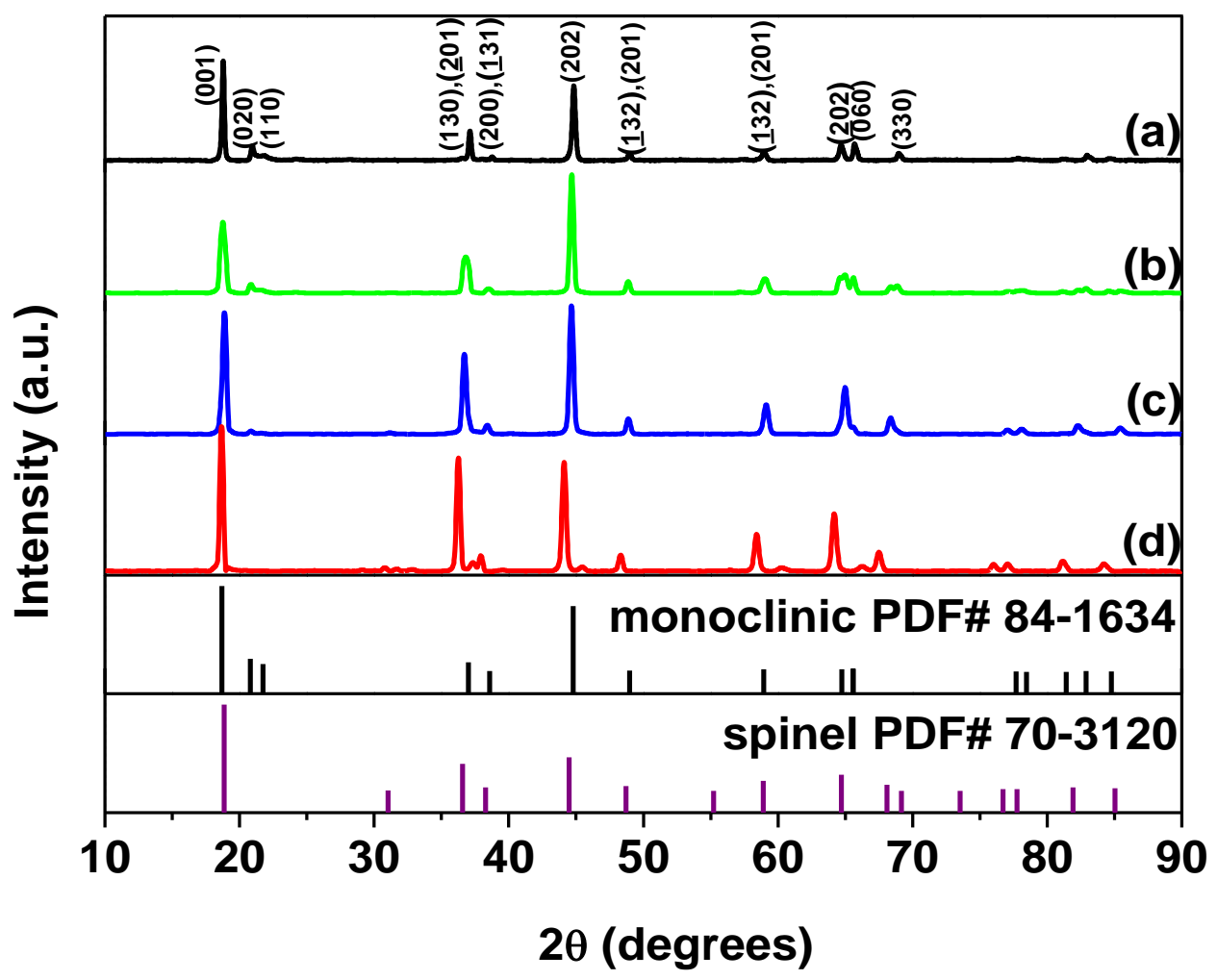

Figure 1. X-ray powder diffraction patterns of (a) $\mathrm{Li}_{2} \mathrm{MnO}_{3}$, (b) $\mathrm{Li}_{1.5} \mathrm{Al}_{0.17} \mathrm{MnO}_{3}$, (c) $\mathrm{Li}_{1.0} \mathrm{Al}_{0.33} \mathrm{MnO}_{3}$ and (d) $\mathrm{Li}_{0.5} \mathrm{Al}_{0.5} \mathrm{MnO}_{3}$ compounds.

Table 2. Lattice parameters of $\mathrm{Li}_{1.5} \mathrm{Al}_{0.17} \mathrm{MnO}_{3}, \mathrm{Li}_{1.0} \mathrm{Al}_{0.33} \mathrm{MnO}_{3}$ and $\mathrm{Li}_{0.5} \mathrm{Al}_{0.5} \mathrm{MnO}_{3}$ based on the spinel (cubic) structure.

\begin{tabular}{lccc}
\hline Composition & $a(\AA)$ & $\alpha=\beta=\gamma$ & $V\left(A^{3}\right)$ \\
\hline Spinel $\mathbf{L i M n}_{\mathbf{2}} \mathbf{O}_{\mathbf{4}}$ (cubic)* & 8.2210 & 90 & 555.6 \\
$\mathbf{L i}_{\mathbf{1 . 5}} \mathbf{A l}_{\mathbf{0 . 1 7}} \mathbf{M n O}_{\mathbf{3}}$ & 8.9330 & 90 & 712.8 \\
$\mathbf{L i}_{\mathbf{1 . 0}} \mathbf{A l}_{\mathbf{0 . 3 3}} \mathbf{M n O}_{\mathbf{3}}$ & 8.5182 & 90 & 618.1 \\
$\mathbf{L i}_{\mathbf{0 . 5}} \mathbf{A l}_{\mathbf{0 . 5}} \mathbf{M n O}_{\mathbf{3}}$ & 8.3495 & 90 & 582.1
\end{tabular}

*Fitted using the PDF\# 70-3120. 
Table 1. All the compositions contain a spinel phase in addition to the monoclinic structure due to the substitution of aluminum ions. Table 2 shows the lattice parameters for the Al-substituted $\mathrm{Li}_{2} \mathrm{MnO}_{3}$ compounds based on the fitting for a spinel phase. As we increase the amount of aluminum substitution, the 'a' lattice parameter approaches the value for the spinel phase, demonstrating the influence of aluminum ions towards the formation of a spinel phase. On the other hand, when observing the lattice parameters based on fitting for a monoclinic phase, it seems that the compounds with the lowest substitution of aluminum have similar lattice parameters values as the monoclinic phase. Based on the observations made by XRD analysis we conclude that spinel phase will be more prominent as we increase the amount of Al substitution.

\subsection{Neutron Diffraction:}

To further understand the structure, neutron diffraction measurement was performed on one of the compositions $\left(\mathrm{Li}_{1.0} \mathrm{Al}_{0.33} \mathrm{MnO}_{3}\right)$. A combined X-ray/neutron Rietveld refinement was performed with a GSAS software. The results of the refinements are presented in Table $\mathbf{3}$ and Table 4. The refinement presented in Fig. 2, shows that the sample is a mixture of two phases: Monoclinic $(\mathrm{C} 2 / \mathrm{m}) \mathrm{Li}_{2} \mathrm{MnO}_{3}$, and Spinel $(\mathrm{Li}, \mathrm{Al})(\mathrm{Mn}, \mathrm{Al})_{2} \mathrm{O}_{4}$. We tested mainly 4 possibilities assigning aluminum to (a) lithium site in the monoclinic phase, (b) manganese site in the monoclinic phase, (c) lithium site in the spinel phase and (d) manganese site in the spinel phase. Out of these 4 possibilities, the assignment of $\mathrm{Al}$ to $\mathrm{Mn}$ site in the spinel phase best describes our data. 


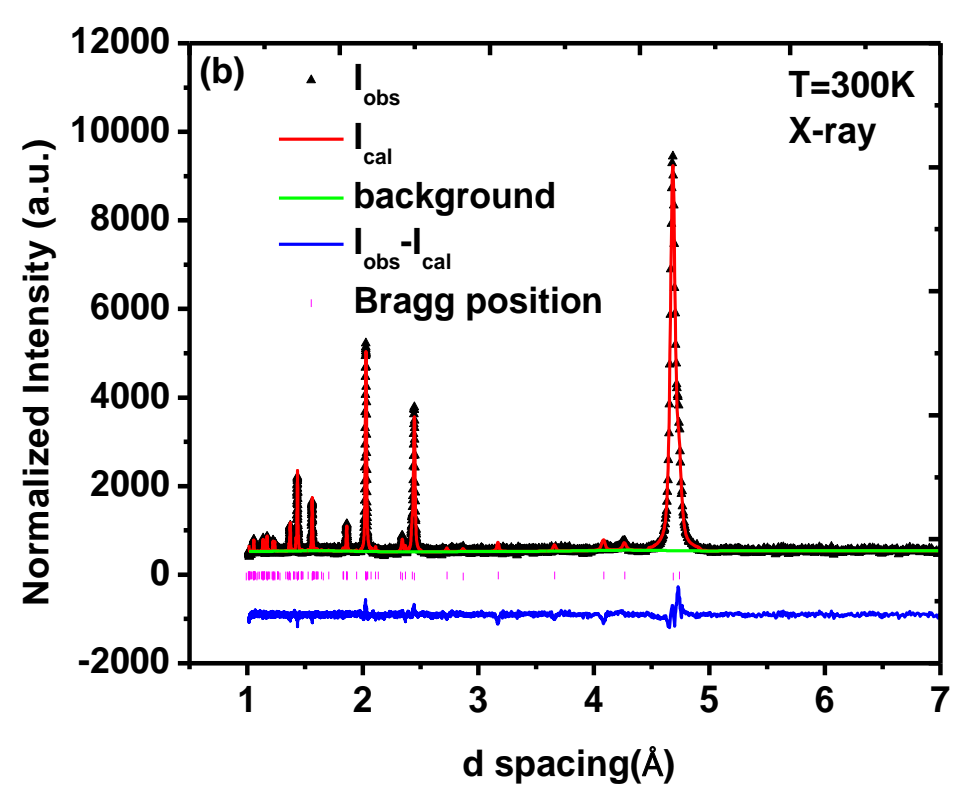

Figure 2. Neutron diffraction (a) Phase I: Monoclinic (b) Phase II: Spinel. 
Table 3. Time of flight (TOF) neutron diffraction measurement refinements for the monoclinic phase.

\begin{tabular}{|c|c|c|c|c|c|c|c|c|c|c|}
\hline \multicolumn{4}{|c|}{$\begin{array}{l}\text { Phase } \mathrm{I} \\
\text { Monoclinic } \mathrm{Li}_{2} \mathrm{MnO}_{3} \\
\mathrm{a}=4.9278(6) b=8.5351(9) \quad \mathrm{b}= \\
\alpha=90 \quad \beta=109.201(8) \quad \gamma=90 \\
\text { Space group: } \mathrm{C} 2 / \mathrm{m} \\
\text { Composition: } \operatorname{Li2}(0) \mathrm{Mn1}(0) \mathrm{O}(0) \\
\text { Wt. fraction=0.19 } \pm 0.004\end{array}$} & \multicolumn{2}{|c|}{$5.02012(35)$} & \multirow[b]{2}{*}{ esd } & \multirow[b]{2}{*}{ Uiso } & \multirow[b]{2}{*}{ esd } & \multirow[b]{2}{*}{ occupancy } & \multirow[b]{2}{*}{ esd } \\
\hline Name & $\mathrm{X}$ & esd & $\mathrm{Y}$ & esd & Z & & & & & \\
\hline Li1 & 0.000 & 0.000 & 0.500 & 0.000 & 0.000 & 0.000 & 0.006 & 0.000 & 1.000 & 0.000 \\
\hline Al1 & 0.000 & 0.000 & 0.500 & 0.000 & 0.000 & 0.000 & 0.005 & 0.000 & 0.000 & 0.000 \\
\hline Mn1 & 0.000 & 0.000 & 0.500 & 0.000 & 0.000 & 0.000 & 0.005 & 0.000 & 0.000 & 0.000 \\
\hline Li2 & 0.000 & 0.000 & 0.000 & 0.000 & 0.500 & 0.000 & 0.006 & 0.000 & 1.000 & 0.000 \\
\hline Al2 & 0.000 & 0.000 & 0.000 & 0.000 & 0.500 & 0.000 & 0.005 & 0.000 & 0.000 & 0.000 \\
\hline $\mathrm{Mn} 2$ & 0.000 & 0.000 & 0.000 & 0.000 & 0.500 & 0.000 & 0.005 & 0.000 & 0.000 & 0.000 \\
\hline Li3 & 0.000 & 0.000 & 0.681 & 0.000 & 0.500 & 0.000 & 0.005 & 0.000 & 1.000 & 0.000 \\
\hline $\mathrm{Al} 3$ & 0.000 & 0.000 & 0.681 & 0.000 & 0.500 & 0.000 & 0.005 & 0.000 & 0.000 & 0.000 \\
\hline Mn3 & 0.000 & 0.000 & 0.681 & 0.000 & 0.500 & 0.000 & 0.005 & 0.000 & 0.000 & 0.000 \\
\hline Mn4 & 0.000 & 0.000 & 0.170 & 0.000 & 0.000 & 0.000 & 0.001 & 0.000 & 1.000 & 0.000 \\
\hline $\mathrm{O} 1$ & 0.271 & 0.000 & 0.000 & 0.000 & 0.213 & 0.000 & 0.027 & 0.000 & 1.000 & 0.000 \\
\hline $\mathrm{O} 2$ & 0.232 & 0.000 & 0.335 & 0.000 & 0.227 & 0.000 & 0.007 & 0.000 & 1.000 & 0.000 \\
\hline Li1A & 0.000 & 0.000 & 0.500 & 0.000 & 0.000 & 0.000 & 0.015 & 0.000 & 0.000 & 0.000 \\
\hline Li2A & 0.000 & 0.000 & 0.000 & 0.000 & 0.500 & 0.000 & 0.015 & 0.000 & 0.000 & 0.000 \\
\hline Li3A & 0.000 & 0.000 & 0.681 & 0.000 & 0.500 & 0.000 & 0.015 & 0.000 & 0.000 & 0.000 \\
\hline Li4A & 0.000 & 0.000 & 0.168 & 0.000 & 0.000 & 0.000 & 0.015 & 0.000 & 0.000 & 0.000 \\
\hline
\end{tabular}


Table 4. Time of flight (TOF) neutron diffraction measurement refinements for the spinel phase.

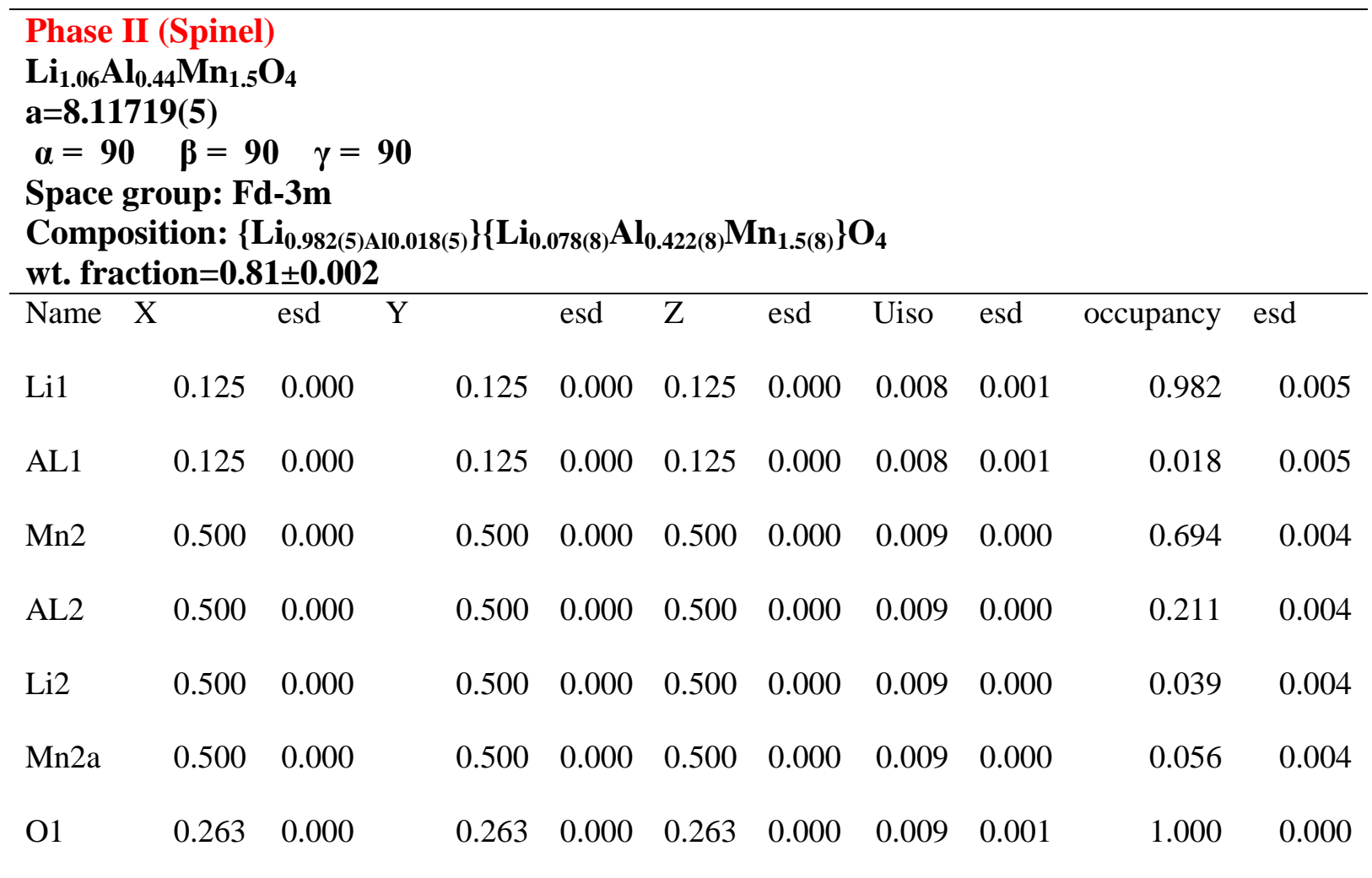

\subsection{Raman scattering:}

In order to fully understand the effect of $\mathrm{Al}$ substitution on the structure of $\mathrm{Li}_{2} \mathrm{MnO}_{3}$, Raman spectra was obtained (Fig. 3). The Raman spectra for the pristine $\mathrm{Li}_{2} \mathrm{MnO}_{3}$ cathode material, shown in Fig. 3a, exhibits nine resolved peaks at 248, 309, 323, 368, 414, 431, 487, 559 and $607 \mathrm{~cm}^{-1}$, which are in good agreement with those reported by Amalraj et al. [23]. According to their theoretical calculations, the monoclinic $\mathrm{Li}_{2} \mathrm{MnO}_{3}$ oxide with $\mathrm{C}_{2 \mathrm{~h}}{ }^{3}$ spectroscopic symmetry is predicted to show ten Raman-active modes with $4 \mathrm{~A}_{\mathrm{g}}+6 \mathrm{~B}_{\mathrm{g}}$ species. The peaks at low wavenumbers are linked to the vibration of the $\mathrm{LiO}_{6}$ octahedral and to the OMn-O bending modes $\left(\mathrm{B}_{\mathrm{g}}\right.$ modes), while high wavenumber peaks are related to the stretching 
modes of the Mn-O bonds ( $\mathrm{A}_{\mathrm{g}}$ modes) [24-26]. These later vibrations are mostly due to the O-O motions since $\mathrm{Mn}$ ions located at the octahedron center do not vibrate in the Raman $\mathrm{A}_{\mathrm{g}}$ modes. The Raman spectra of $\mathrm{Li}_{1.5} \mathrm{Al}_{0.17} \mathrm{MnO}_{3}$ are almost identical to that of the pristine sample, with a slight shift that is within the acceptable range. An additional peak occurs at $654 \mathrm{~cm}^{-1}$ which is attributed to the presence of $\mathrm{Al}-\mathrm{O}$ bonds. The Raman spectra of $\mathrm{Li}_{1.0} \mathrm{Al}_{0.33} \mathrm{MnO}_{3}$ and $\mathrm{Li}_{0.5} \mathrm{Al}_{0.5} \mathrm{MnO}_{3}$ (Fig. 3b) display a different profile that indicates different structural arrangement of atoms in the lattice. The spectrum contains seven bands at 350, 394, 431, 479, 540, 605, and $646 \mathrm{~cm}^{-1}$ for $\mathrm{Li}_{1.0} \mathrm{Al}_{0.33} \mathrm{MnO}_{3}$ and nine bands at 278, 328, 360, 402, 454, 486, 547, 597 and 630 $\mathrm{cm}^{-1}$ for $\mathrm{Li}_{0.5} \mathrm{Al}_{0.5} \mathrm{MnO}_{3}$. The substitution of $\mathrm{Li}$ with $\mathrm{Al}$ induces the presence of an additional phase with a spinel structure.
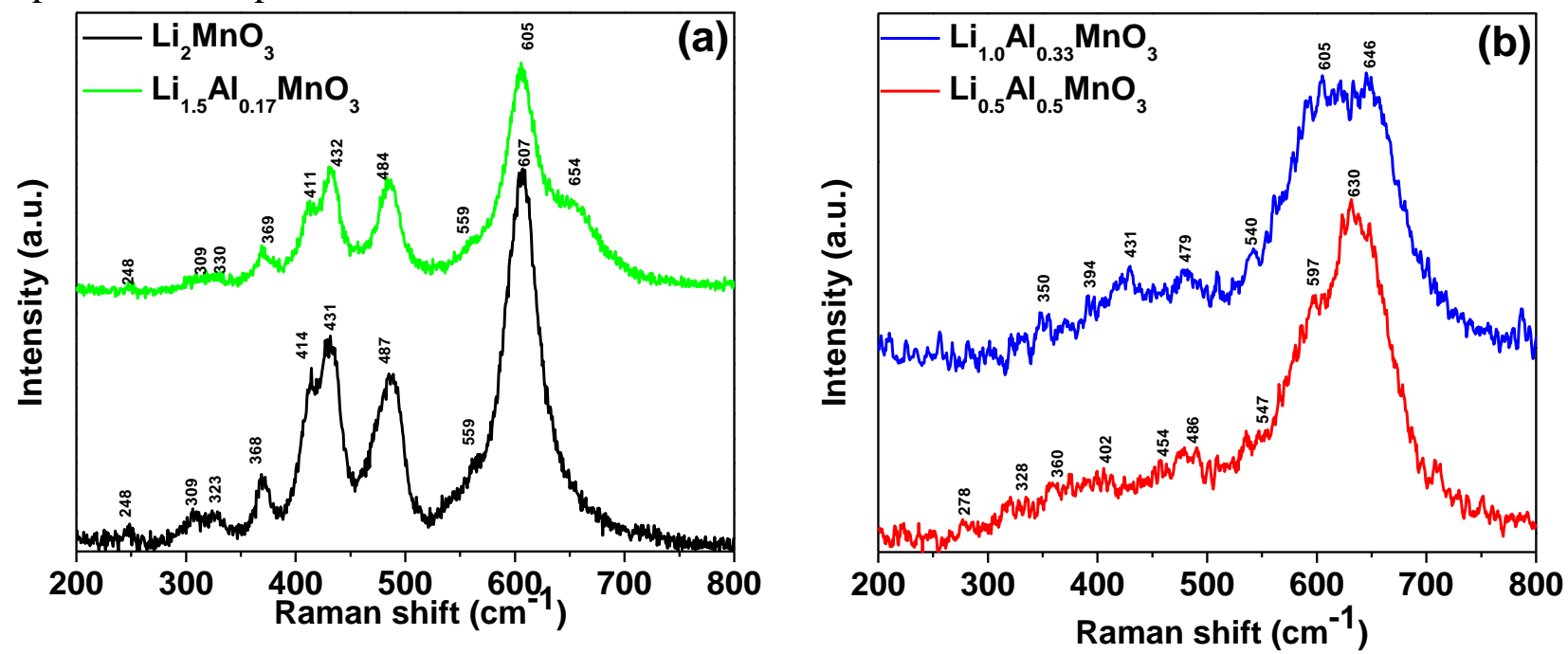

Figure 3. Raman scattering spectra of (a) $\mathrm{Li}_{2} \mathrm{MnO}_{3}, \mathrm{Li}_{1.5} \mathrm{Al}_{0.17} \mathrm{MnO}_{3}$ and (b) $\mathrm{Li}_{1.0} \mathrm{Al}_{0.33} \mathrm{MnO}_{3}$, $\mathrm{Li}_{0.5} \mathrm{Al}_{0.5} \mathrm{MnO}_{3}$.

Preudhome and Tarte [27] claimed that if there are two different octahedra in a structure, with different vibrational frequencies, their vibrational interaction is going to be weak resulting in 
individual contributions to the spectrum at their respective distinctive frequencies. It is the case for $\mathrm{Li}_{1.0} \mathrm{Al}_{0.33} \mathrm{MnO}_{3}$ and $\mathrm{Li}_{0.5} \mathrm{Al}_{0.5} \mathrm{MnO}_{3}$ framework, which contains $\mathrm{MnO}_{6}$ and $\mathrm{AlO}_{6}$ octahedra. Following this thought, the high wavenumber peak of $\mathrm{Li}_{1.0} \mathrm{Al}_{0.33} \mathrm{MnO}_{3}$ and $\mathrm{Li}_{0.5} \mathrm{Al}_{0.5} \mathrm{MnO}_{3}$ located at $646 \mathrm{~cm}^{-1}$ and $630 \mathrm{~cm}^{-1}$ respectively, is due to the stretching modes of the Al-O bonds ( $A_{1 g}$ mode), while the low wavenumber peaks at 540, 479, 431, 394 and $350 \mathrm{~cm}^{-1}$ for $\mathrm{Li}_{1.0} \mathrm{Al}_{0.33} \mathrm{MnO}_{3}$ and 547, 486, 454, 402, 360, 328 and $278 \mathrm{~cm}^{-1}$ for $\mathrm{Li}_{0.5} \mathrm{Al}_{0.5} \mathrm{MnO}_{3}$ have the $\mathrm{T}_{2 \mathrm{~g}}$ character for the (Mn, Al)-O bond vibrations.

\subsection{SEM and EDX:}
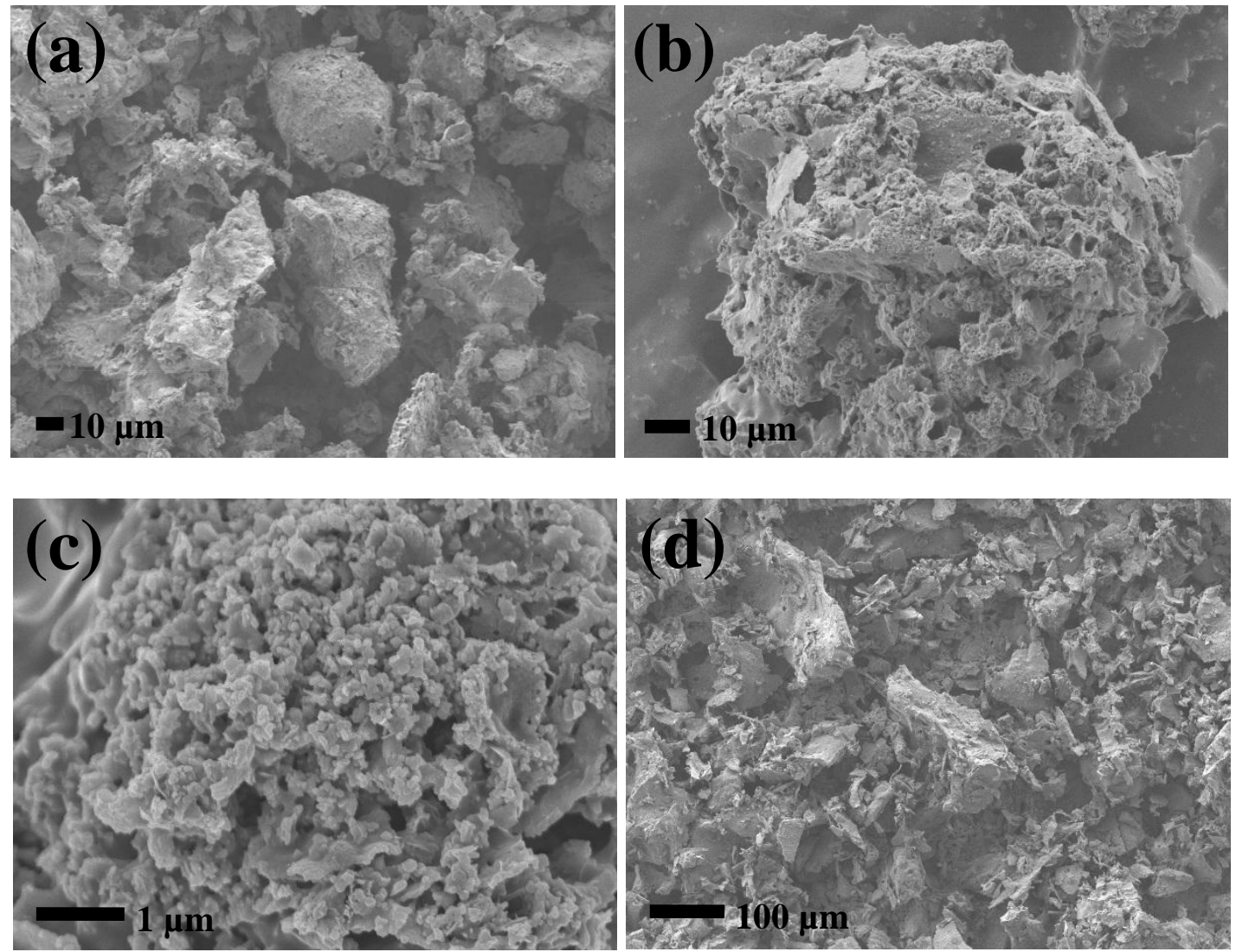

Figure 4. Scanning electron microscopy images of (a) $\mathrm{Li}_{2} \mathrm{MnO}_{3}$, (b) $\mathrm{Li}_{1.5} \mathrm{Al}_{0.17} \mathrm{MnO}_{3}$, 
(c) $\mathrm{Li}_{1.0} \mathrm{Al}_{0.33} \mathrm{MnO}_{3}$ and (d) $\mathrm{Li}_{0.5} \mathrm{Al}_{0.5} \mathrm{MnO}_{3}$.

The powder morphology of the synthesized samples was analyzed with SEM. It is important to determine the particle size of the materials because it is known that electrochemical performance of an electrode is strongly dependent on the particle size. For small particle size, the specific surface area is higher, allowing easy kinetics for insertion/extraction of $\mathrm{Li}^{+}$ions leading to high energy density. The SEM images are shown in Fig. 4, where the materials synthesized with the sol-gel Pechini method resulted in the formation of agglomerates. It can be observed that the particle size of the pristine $\mathrm{Li}_{2} \mathrm{MnO}_{3}$ and $\mathrm{Al}$-substituted compounds are similar and are displaying high agglomeration of the primary particles. EDX analysis performed over the agglomerated area and its surrounding indicates the existence of the respective elements in the compounds.

\subsection{BET Analysis:}

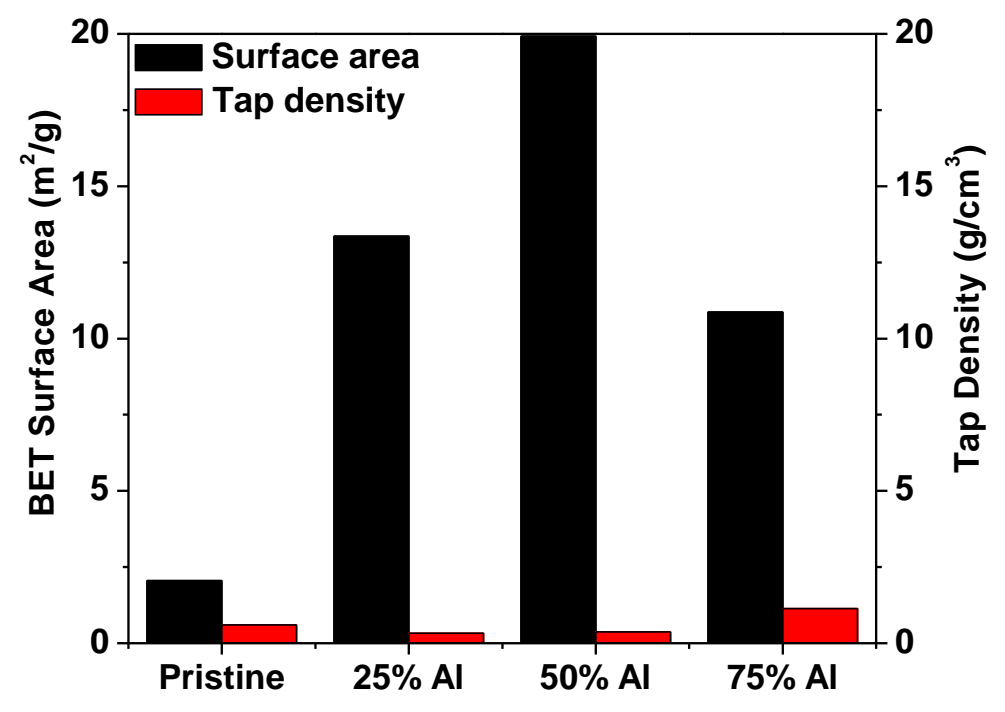

Figure 5. BET surface area and tap density analysis of $\mathrm{Li}_{2} \mathrm{MnO}_{3}$ and $\mathrm{Al}$-substituted compounds. 
The BET surface area was measured for the samples using nitrogen adsorptiondesorption isotherms. The surface area for $\mathrm{Li}_{2} \mathrm{MnO}_{3}, \mathrm{Li}_{1.5} \mathrm{Al}_{0.17} \mathrm{MnO}_{3}$ (25\% Al-substitution), $\mathrm{Li}_{1.0} \mathrm{Al}_{0.33} \mathrm{MnO}_{3} \quad(50 \%$ Al-substitution $)$ and $\mathrm{Li}_{0.5} \mathrm{Al}_{0.5} \mathrm{MnO}_{3} \quad(75 \%$ Al-substitution $)$ were determined to be 2.05, 13.36, 19.92 and $10.87 \mathrm{~m}^{2} \mathrm{~g}^{-1}$ respectively as shown in Fig. 5. Amalraj et al. reported a surface area for the pristine $\mathrm{Li}_{2} \mathrm{MnO}_{3}$ synthesized by a solid-state route to be 0.86 $\mathrm{m}^{2} \mathrm{~g}^{-1}$ [14]. Therefore, the sol-gel Pechini method doubles the surface area of $\mathrm{Li}_{2} \mathrm{MnO}_{3}$. In addition, the BET surface area for Al-substituted samples is significantly higher compared to the pristine $\mathrm{Li}_{2} \mathrm{MnO}_{3}$. Tap density analysis was performed for the compounds to complement the BET measurements since high surface area is inversely proportional to the packing density. $\mathrm{Li}_{0.5} \mathrm{Al}_{0.5} \mathrm{MnO}_{3}$ exhibits a higher tap density and a smaller surface area among the Al-substituted compounds. The combination of both properties suggests that this compound will exhibit a higher energy density and a better cycle stability.

\subsection{XPS:}

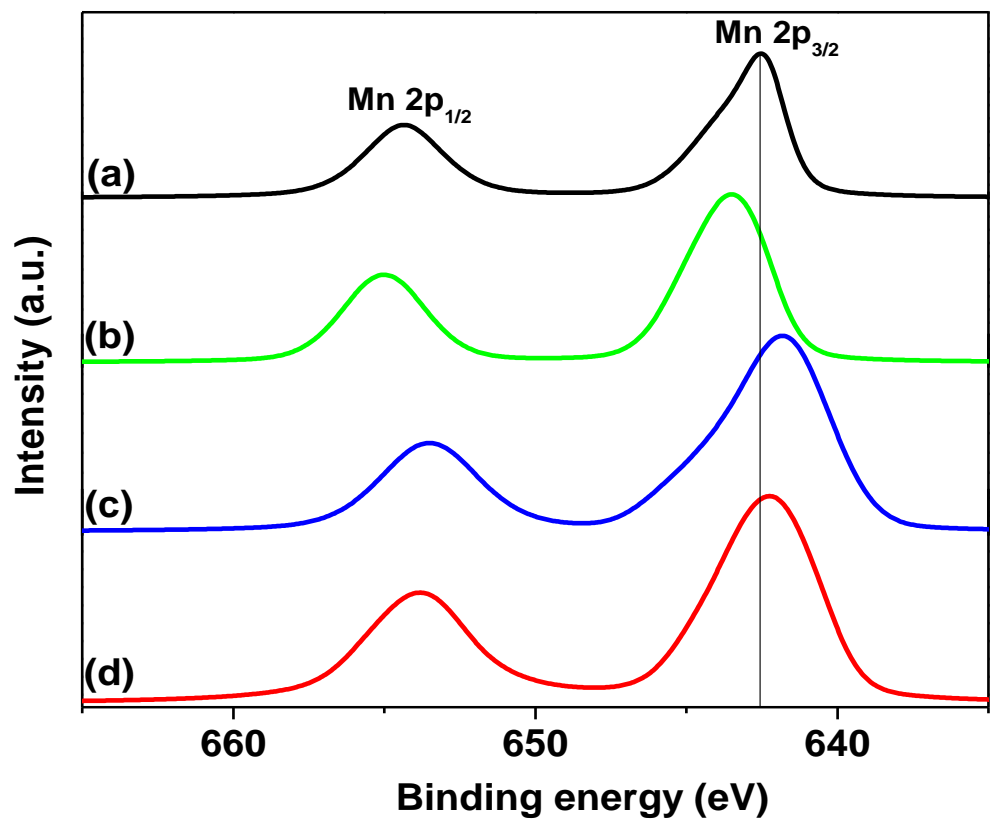


Figure 6. XPS spectra of (a) $\mathrm{Li}_{2} \mathrm{MnO}_{3}$, (b) $\mathrm{Li}_{1.5} \mathrm{Al}_{0.17} \mathrm{MnO}_{3}$, (c) $\mathrm{Li}_{1.0} \mathrm{Al}_{0.33} \mathrm{MnO}_{3}$ and (d) $\mathrm{Li}_{0.5} \mathrm{Al}_{0.5} \mathrm{MnO}_{3}$

As mentioned before, the main objective of this work is to reduce the Mn valence state and investigate the electrochemical properties for improved cycling capacity. In order to understand the effects of these Al substitutions on the valence state of Mn, XPS spectra of the materials were performed. The XPS results presented in Fig. 6 indicate that Mn $2 p$ spectra exhibited two major peaks due to the spin-orbit splitting for all compositions. The Mn $2 \mathrm{p}_{1 / 2}$ and Mn $2 \mathrm{p}_{3 / 2}$ binding energy values for the pristine $\mathrm{Li}_{2} \mathrm{MnO}_{3}$ are $654.10 \mathrm{eV}$ and $642.30 \mathrm{eV}$, respectively, with a binding energy splitting of $11.8 \mathrm{eV}$. The XPS data for Mn $2 \mathrm{p}$ orbital for the Al-substituted compounds is presented in Table 5. The $\mathrm{Mn} 2 \mathrm{p}_{3 / 2}$ peak for $\mathrm{Li}_{1.0} \mathrm{Al}_{0.33} \mathrm{MnO}_{3}$ and $\mathrm{Li}_{0.5} \mathrm{Al}_{0.5} \mathrm{MnO}_{3}$ is significantly shifted to a lower binding energy $(641.90 \mathrm{eV}$ and $642.25 \mathrm{eV}$, respectively) compared to the pristine $\mathrm{Li}_{2} \mathrm{MnO}_{3}(642.30 \mathrm{eV})$. The change to a lower binding energy is an indication of a reduction in the valence state of manganese $\left(\mathrm{Mn}^{<4+}\right)$ which could enable this material to cycle with an enhanced capacity. In the case of $\mathrm{Li}_{1.5} \mathrm{Al}_{0.17} \mathrm{MnO}_{3}$, the peaks are slightly shifted to higher binding energies, indicating no change in the valence state of manganese. The lower binding energy obtained from XPS results for $\mathrm{Li}_{1.0} \mathrm{Al}_{0.33} \mathrm{MnO}_{3}$ and $\mathrm{Li}_{0.5} \mathrm{Al}_{0.5} \mathrm{MnO}_{3}$ compounds suggest we could expect an improvement in the electrochemical performance. 
Table 5. XPS binding energies for Mn 2p orbital.

\begin{tabular}{llll}
\hline Composition & B.E. $(\mathrm{eV}) \mathrm{Mn} 2 p_{1 / 2}$ & B.E.(eV) $M n 2 p_{3 / 2}$ & $\Delta$ B.E. Mn 2p(eV) \\
\hline $\mathbf{L i}_{\mathbf{2}} \mathbf{M n O} \mathbf{O}_{\mathbf{3}}$ & 654.10 & 642.30 & 11.80 \\
$\mathbf{L i}_{\mathbf{1 . 5}} \mathbf{A l}_{\mathbf{0 . 1 7}} \mathbf{M n O}_{\mathbf{3}}$ & 655.10 & 643.40 & 11.70 \\
$\mathbf{L i}_{\mathbf{1 . 0}} \mathbf{A l}_{\mathbf{0 . 3 3}} \mathbf{M n O}_{\mathbf{3}}$ & 653.50 & 641.90 & 11.60 \\
$\mathbf{L i}_{\mathbf{0 . 5}} \mathbf{A l}_{\mathbf{0 . 5}} \mathbf{M n O}_{\mathbf{3}}$ & 653.85 & 642.25 & 11.60
\end{tabular}

3.7. Electrochemical characterization:
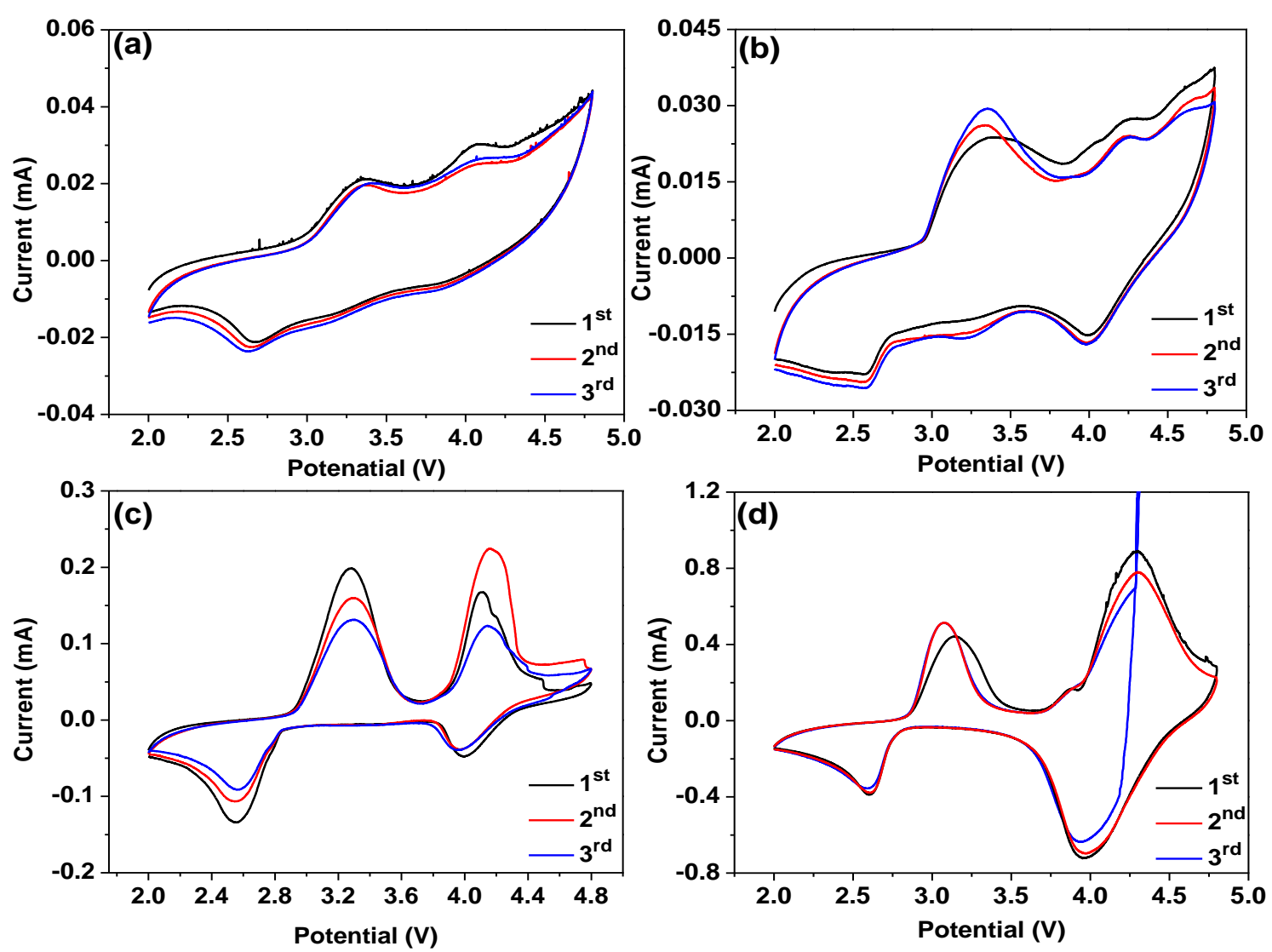

Figure 7. Cyclic voltammograms of (a) $\mathrm{Li}_{2} \mathrm{MnO}_{3}$, (b) $\mathrm{Li}_{1.5} \mathrm{Al}_{0.17} \mathrm{MnO}_{3}$, (c) $\mathrm{Li}_{1.0} \mathrm{Al}_{0.33} \mathrm{MnO}_{3}$ and (d) $\mathrm{Li}_{0.5} \mathrm{Al}_{0.5} \mathrm{MnO}_{3}$ in the voltage range of $2.0-4.8 \mathrm{~V}$ with a scan rate of $0.1 \mathrm{mV} / \mathrm{s}$. 
The electrochemical performance of the cathode materials was investigated with cyclic voltammetry $(\mathrm{CV})$ to observe the redox processes. The potential window used was $2.0-4.8 \mathrm{~V}$ at a scanning rate of $0.1 \mathrm{mV} \mathrm{s}^{-1}$. Three consecutive $\mathrm{CV}$ measurements were performed to understand the redox reaction before and after charge/discharge cycles. The first $\mathrm{CV}$ for $\mathrm{Li}_{2} \mathrm{MnO}_{3}$, shown in Fig. 7(a), presents the distinctive anodic and cathodic peaks for this material at 3.33 and $2.67 \mathrm{~V}$, respectively. A broader oxidation peak is observed around $4.07 \mathrm{~V}$, which is the evidence for phase transition in the structure from layer to spinel as reported in the literature [28]. After each cyclic voltammetry, the current intensity at the anodic peak was decreasing and the voltage shifted to higher potential values. On the contrary, the cathodic peak current intensity was increasing and moving to lower potentials, which reveal a separation between the anodic and cathodic peaks, indicative of an irreversible process. The CV behavior for the Al-substituted compounds is similar to spinel phase materials as well as monoclinic $\mathrm{Li}_{2} \mathrm{MnO}_{3}$, which was expected since spinel phase was observed in both XRD and RAMAN analysis. The oxidation and reduction peaks for the spinel phase materials correspond to the process associated with $\mathrm{Mn}^{4+} / \mathrm{Mn}^{3+}$ but in our case the oxidation peaks corresponds to $\mathrm{Mn}^{4+} / \mathrm{Mn}^{3.5-3.9+}$ as shown by XPS analysis. In addition, pure spinel phase presents a lower separation of peak potentials compared to our compounds, which indicates the combination of two phases (monoclinic along with spinel) for the Al-substituted $\mathrm{Li}_{2} \mathrm{MnO}_{3}$. Cyclic voltammogram of $\mathrm{Li}_{1.5} \mathrm{Al}_{0.17} \mathrm{MnO}_{3}$ showed a similar behavior to the pristine sample (Fig. 7b). The anodic peak at $\sim 4.68 \mathrm{~V}$ is due to the partial extraction of lithium and oxygen ions from the structure. In the case of $\mathrm{Li}_{1.0} \mathrm{Al}_{0.33} \mathrm{MnO}_{3}$, (Fig. 7c), two anodic peaks at $3.29 \mathrm{~V}$ and $4.17 \mathrm{~V}$ were observed. The current intensity of the first anodic peak decreases after each $\mathrm{CV}$, while the voltage remains fairly similar. The second 
cathodic peak exhibited a shift to lower potential values with a slight increase in current after each cycle indicating the irreversible process during the electrochemical performance. Similarly, the first $\mathrm{CV}$ for $\mathrm{Li}_{0.5} \mathrm{Al}_{0.5} \mathrm{MnO}_{3}$ (Fig. 7d) depicts well-defined anodic and cathodic peaks. The intensities of the oxidation and reduction peaks are higher and sharper than pristine $\mathrm{Li}_{2} \mathrm{MnO}_{3}$. The second CV exhibited a reduction in the voltage for the first anodic peak from $3.15 \mathrm{~V}$ to 3.07V, while the current increased to $0.51 \mathrm{~mA}$ from $0.44 \mathrm{~mA}$. In addition, the second anodic peak at 4.28 V confirms the presence of spinel phase in the structure, as observed in XRD and Raman. In the case of the peak around $2.61 \mathrm{~V}$, a small change in voltage and current is observed after the first CV. However, the current intensity and peak potential remain the same for the second and third CV scans.

The charge-discharge curves for pristine and Al-substituted $\mathrm{Li}_{2} \mathrm{MnO}_{3}$ are shown in Fig. 8 . The current density used was $10 \mathrm{~mA} \mathrm{~g}^{-1}$ for a potential window of $2.8-4.8 \mathrm{~V}$. Table 6 presents the first charge and discharge capacity of the compounds as well as the coulombic efficiency of the $1^{\text {st }}$ and $50^{\text {th }}$ cycle. First galvanostatic charge/discharge profile for $\mathrm{Li}_{2} \mathrm{MnO}_{3}$ shows a plateau at 4.5 V (Fig. 8a) that is related to lithium and oxygen extraction from the structure [29]. The specific capacity after charging was calculated to be $32 \mathrm{mAh} \mathrm{g}^{-1}$, with a corresponding discharge capacity of $12 \mathrm{mAh} \mathrm{g}^{-1}$. The coulombic efficiency of the first cycle for pristine $\mathrm{Li}_{2} \mathrm{MnO}_{3}$ was $38 \%$ but it improved for consecutive cycles. At $50^{\text {th }}$ cycle, the capacity was approximately $24 \mathrm{mAh} \mathrm{g}^{-1}$ with an efficiency of $90 \%$. These results were expected since monoclinic phase compounds are known for its lack of electrochemical activities during redox process. Fig. $8 b$ exhibits the charge/discharge profile of $\mathrm{Li}_{1.5} \mathrm{Al}_{0.17} \mathrm{MnO}_{3}$ which displays a similar electrochemical behavior as $\mathrm{Li}_{2} \mathrm{MnO}_{3}$, showing higher first cycle discharge capacity of $68 \mathrm{mAh} \mathrm{g}^{-1}$ with an efficiency of $62 \%$. 
After 50 cycles the capacity was around $58-55 \mathrm{mAh} \mathrm{g}^{-1}$ and continued to decrease after each cycle. A plateau at $\sim 4.65 \mathrm{~V}$ is also observed for this compound, which refers to the extraction of lithium and oxygen from the host structure. $\mathrm{Li}_{1.0} \mathrm{Al}_{0.33} \mathrm{MnO}_{3}$ showed an initial discharge capacity of $58 \mathrm{mAh} \mathrm{g}^{-1}$, however, this compound demonstrated the best cycle stability with a discharge capacity in the range of 60-62 $\mathrm{mAh} \mathrm{g}^{-1}$ (Fig. 8c) and coulombic efficiency of $\sim 99 \%$. Chargedischarge curves for $\mathrm{Li}_{0.5} \mathrm{Al}_{0.5} \mathrm{MnO}_{3}$ are shown in Fig. 8d and the initial discharge capacity exhibited $81 \%$ efficiency $\left(74 \mathrm{mAh} \mathrm{g}^{-1}\right)$ compared to pristine $\mathrm{Li}_{2} \mathrm{MnO}_{3}\left(20 \mathrm{mAh} \mathrm{g}{ }^{-1}\right)$. After 50 cycles, the capacity was $\sim 70 \mathrm{mAh} \mathrm{g}^{-1}$ with a coulombic efficiency of $99 \%$. The enhance electrochemical performance for the Al-substituted compounds is related to the ability of aluminum to occupy manganese site and lithium site simultaneously, which force the valance state of manganese to decrease in order to balance the charge as shown from XPS results. 
Figure 8. Charge-discharge profiles of (a) $\mathrm{Li}_{2} \mathrm{MnO}_{3}$, (b) $\mathrm{Li}_{1.5} \mathrm{Al}_{0.17} \mathrm{MnO}_{3}$, (c) $\mathrm{Li}_{1.0} \mathrm{Al}_{0.33} \mathrm{MnO}_{3}$ and (d) $\mathrm{Li}_{0.5} \mathrm{Al}_{0.5} \mathrm{MnO}_{3}$ using a current density of $10 \mathrm{mAh} \mathrm{g}{ }^{-1}$.
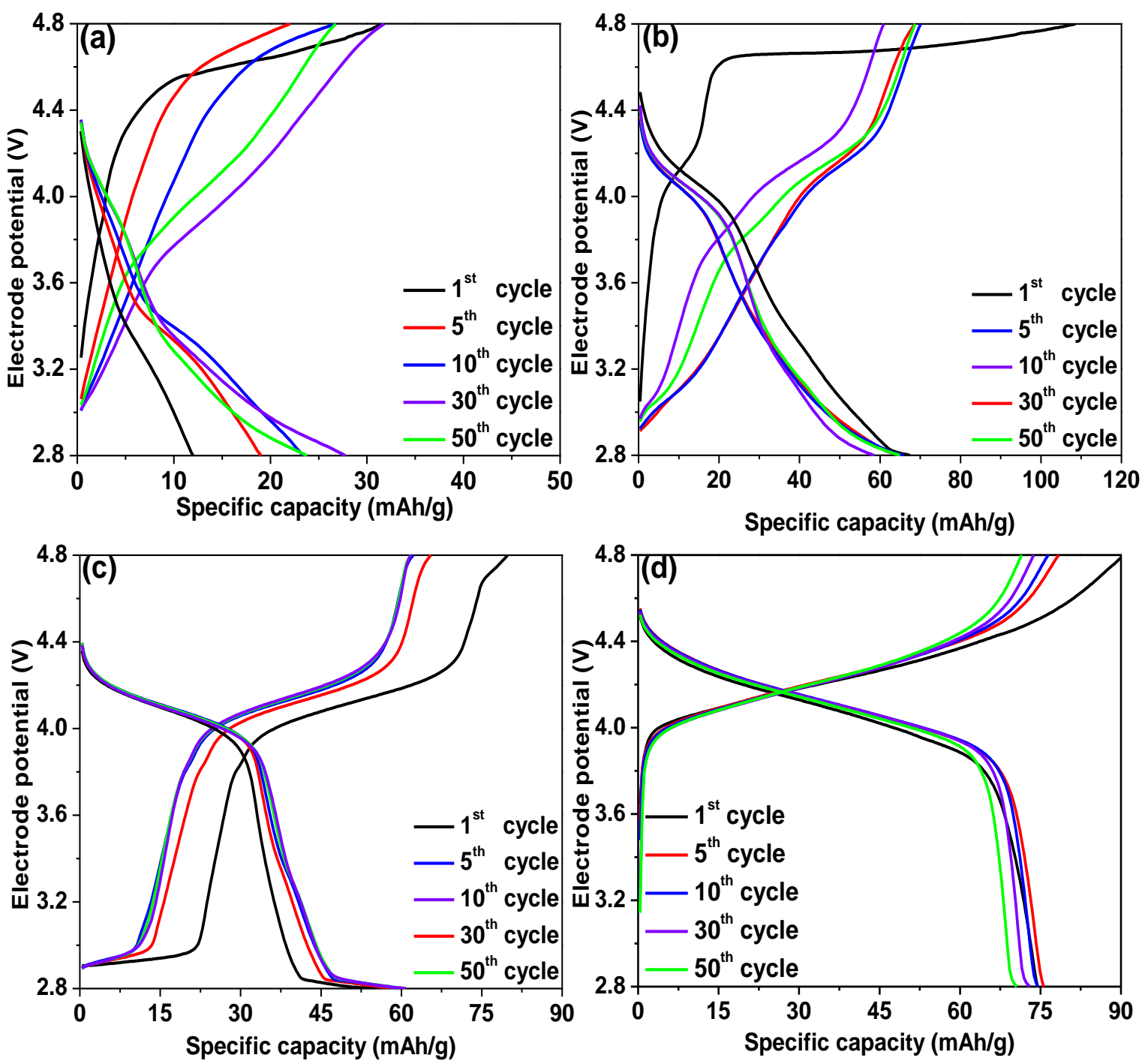
Table 6. Initial electrochemical performance.

\begin{tabular}{lllll}
\hline Composition & $\begin{array}{l}1^{\text {st }} \text { charge } \\
\text { capacity }(m A h / g)\end{array}$ & $\begin{array}{l}1^{\text {st }} \text { discharge } \\
\text { capacity }(\mathrm{mAh} / \mathrm{g})\end{array}$ & $\begin{array}{l}\text { Coulombic } \\
\text { Efficiency }(\%) \\
1^{\text {st }} \text { cycle }\end{array}$ & $\begin{array}{l}\text { Coulombic } \\
\text { Efficiency }(\%) \\
50^{\text {th }} \text { cycle }\end{array}$ \\
\hline $\mathbf{L i}_{\mathbf{2}} \mathbf{M n O}_{\mathbf{3}}$ & 32 & 12 & $38 \%$ & $90 \%$ \\
$\mathbf{L i}_{\mathbf{1 . 5}} \mathbf{A l}_{\mathbf{0 . 1 7}} \mathbf{M n O}_{\mathbf{3}}$ & 109 & 68 & $62 \%$ & $96 \%$ \\
$\mathbf{L i}_{\mathbf{1 . 0}} \mathbf{A l}_{\mathbf{0 . 3 3}} \mathbf{M n O}_{\mathbf{3}}$ & 80 & 58 & $73 \%$ & $99 \%$ \\
$\mathbf{L i}_{\mathbf{0 . 5}} \mathbf{A l}_{\mathbf{0 . 5}} \mathbf{M n O}_{\mathbf{3}}$ & 91 & 74 & $81 \%$ & $99 \%$ \\
\hline
\end{tabular}

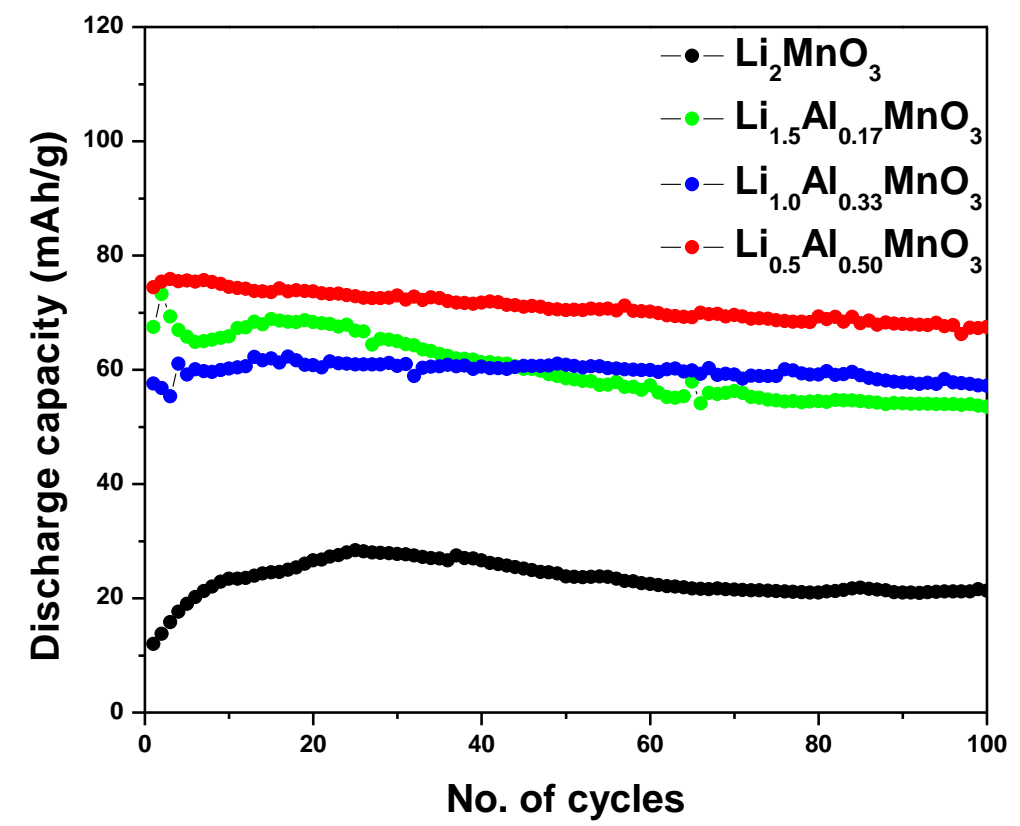

Figure 9. Comparison of the cycling performances for $\mathrm{Li}_{2} \mathrm{MnO}_{3}$ and $\mathrm{Al}$-substituted compounds using a current density of $10 \mathrm{mAh} \mathrm{g}^{-1}$ for 100 cycles.

Fig. 9 shows a comparison of discharge capacity vs. number of cycles for all the cathode materials studied. Pristine $\mathrm{Li}_{2} \mathrm{MnO}_{3}$ initial discharge capacity was $12 \mathrm{mAh} \mathrm{g}^{-1}$ which was 
increasing for the first 25 cycles and eventually stabilized at a discharge capacity of $\sim 23 \mathrm{mAh} \mathrm{g}^{-}$

1. The capacity behavior at the initial cycles is due to the cell formation in the coin cell and the capability of the electrolyte to get good contact with the electrode [30]. $\mathrm{Li}_{0.5} \mathrm{Al}_{0.5} \mathrm{MnO}_{3}$ presents high capacity and good cycle stability compared to Al-substituted compounds and $\mathrm{Li}_{2} \mathrm{MnO}_{3}$. This improvement of the electrochemical performance is attributed to the insertion of aluminum ions into lithium and manganese sites simultaneously, which manage to decrease the valance state of manganese from $4+$ to $3.5-3.8+$. The cycle performance of $\mathrm{Li}_{1.5} \mathrm{Al}_{0.17} \mathrm{MnO}_{3}$ and $\mathrm{Li}_{1.0} \mathrm{Al}_{0.33} \mathrm{MnO}_{3}$ is presenting a slight disorder at the beginning of the charge/discharge analysis but stabilizes after the $15^{\text {th }}$ cycle, presenting the best cycle stability among the Al-substituted compounds.

Electrochemical impedance spectroscopy (EIS) measurements were performed on all the samples in order to monitor the cell resistance during charge/discharge cycles. The results for the pristine $\mathrm{Li}_{2} \mathrm{MnO}_{3}$ and $\mathrm{Al}$-substituted materials are shown in Fig. $\mathbf{1 0}$ in the form of Nyquist plots. Fig. 10a shows the EIS measurements for the compounds before cycling. The initial resistance $\left(\mathrm{R}_{\mathrm{I}}\right)$ of the coin cells and the charge transfer resistance $\left(\mathrm{R}_{\mathrm{CT}}\right)$ are listed in Table $7 . \mathrm{Li}_{2} \mathrm{MnO}_{3}$ exhibited high initial resistance before cycling. However, the resistance decreased for consecutive cycles. A similar behavior was observed for $\mathrm{Li}_{1.5} \mathrm{Al}_{0.17} \mathrm{MnO}_{3}$, where the initial resistance was high but decreased after cycling. The initial resistance for $\mathrm{Li}_{0.5} \mathrm{Al}_{0.5} \mathrm{MnO}_{3}$ before cycling was $\mathrm{R}_{\mathrm{I}}=5.34 \Omega$ and increase to $\mathrm{R}_{\mathrm{I}}=10.54 \Omega$ after three cycles. The same phenomena occur for $\mathrm{Li}_{1.0} \mathrm{Al}_{0.33} \mathrm{MnO}_{3}$, where the initial resistance increased after each cycle. In addition, we analyzed the charge transfer resistance for the compounds before cycling and after three cycles. The charge transfer resistance for the $\mathrm{Li}_{0.5} \mathrm{Al}_{0.5} \mathrm{MnO}_{3}$ compound $\left(\mathrm{R}_{\mathrm{CT}}=30.14 \Omega\right)$ is smaller than 
$\mathrm{Li}_{2} \mathrm{MnO}_{3}\left(\mathrm{R}_{\mathrm{CT}}=1164 \Omega\right), \mathrm{Li}_{1.0} \mathrm{Al}_{0.33} \mathrm{MnO}_{3}\left(\mathrm{R}_{\mathrm{CT}}=603 \Omega\right)$, and $\mathrm{Li}_{1.5} \mathrm{Al}_{0.17} \mathrm{MnO}_{3}\left(\mathrm{R}_{\mathrm{CT}}=1316 \Omega\right)$, indicating that this composition facilitates electron transport at the interface between the electrode and the electrolyte compared to the others samples. Detailed EIS measurements are needed to understand the slow charge transfer at the electrode/electrolyte interface.
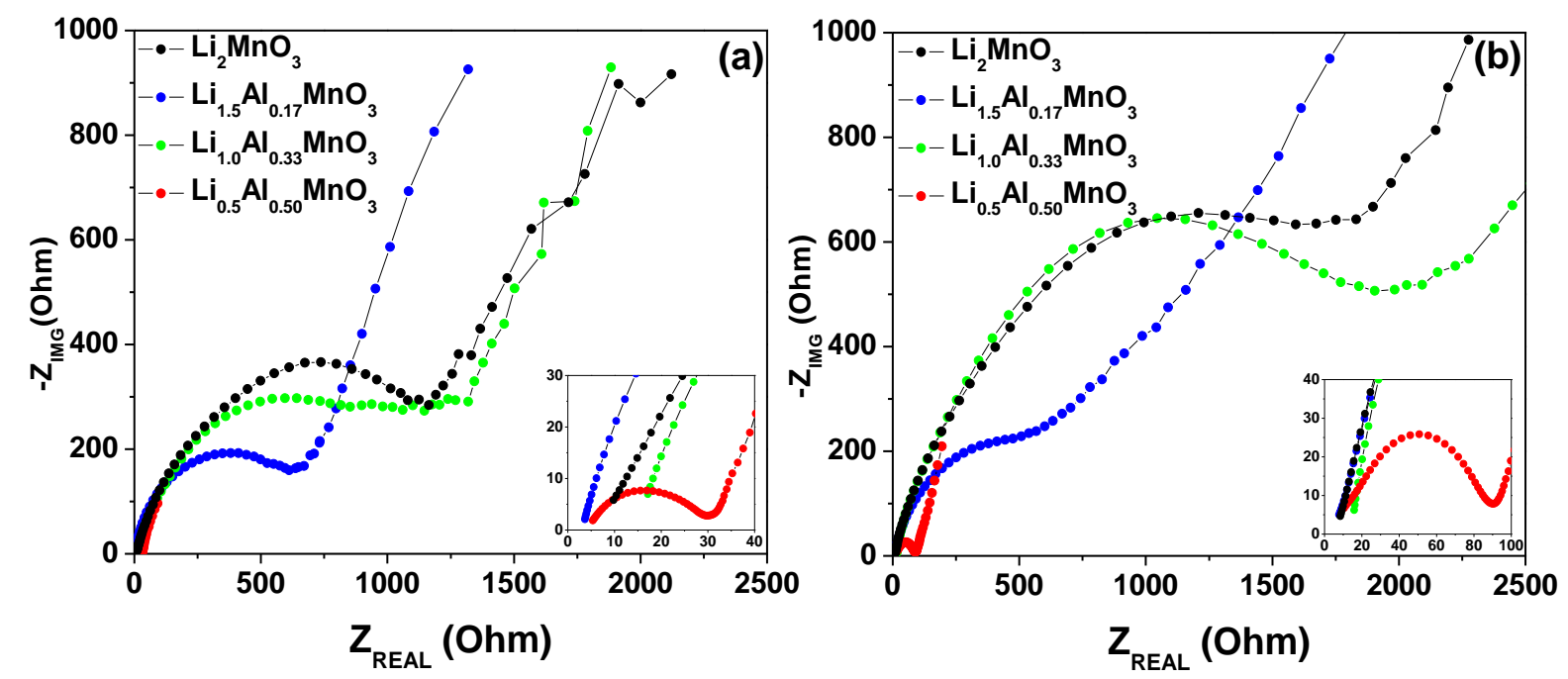

Figure 10. Nyquist plots of $\mathrm{Li}_{2} \mathrm{MnO}_{3}, \mathrm{Li}_{1.5} \mathrm{Al}_{0.17} \mathrm{MnO}_{3}, \mathrm{Li}_{1.0} \mathrm{Al}_{0.33} \mathrm{MnO}_{3}$ and $\mathrm{Li}_{0.5} \mathrm{Al}_{0.5} \mathrm{MnO}_{3}$, (a) before cycling and (b) after three cycles. 
Table 7. Electrochemical impedance spectroscopy (EIS): initial resistance $\left(\mathrm{R}_{\mathrm{I}}\right)$ and charge transfer resistance $\left(\mathrm{R}_{\mathrm{CT}}\right)$ before \& after cycling.

\begin{tabular}{lllll}
\hline Composition & $R_{I}$ before $(\Omega)$ & $R_{I} 3^{\text {rd }}$ cycle $(\Omega)$ & $R_{C T}$ before $(\Omega)$ & $R_{C T} 3^{\text {rd }}$ cycle $(\Omega)$ \\
\hline $\mathbf{L i}_{\mathbf{2}} \mathbf{M n O} \mathbf{O}_{\mathbf{3}}$ & 26.77 & 8.44 & 1164.13 & 1831.10 \\
$\mathbf{L i}_{\mathbf{1 . 5}} \mathbf{A l}_{\mathbf{0 . 1 7}} \mathbf{M n O}_{\mathbf{3}}$ & 17.14 & 15.86 & 1316.08 & 2093.51 \\
$\mathbf{L i}_{\mathbf{1 . 0}} \mathbf{A l}_{\mathbf{0 . 3 3}} \mathbf{M n O}_{\mathbf{3}}$ & 3.65 & 7.77 & 603.07 & 478.68 \\
$\mathbf{L i}_{\mathbf{0 . 5}} \mathbf{A l}_{\mathbf{0 . 5}} \mathbf{M n O}_{\mathbf{3}}$ & 5.34 & 10.54 & 30.14 & 89.55 \\
\hline
\end{tabular}

\section{Conclusions}

$\mathrm{Li}_{2} \mathrm{MnO}_{3}, \quad \mathrm{Li}_{1.5} \mathrm{Al}_{0.17} \mathrm{MnO}_{3}, \quad \mathrm{Li}_{1.0} \mathrm{Al}_{0.33} \mathrm{MnO}_{3}$ and $\mathrm{Li}_{0.5} \mathrm{Al}_{0.5} \mathrm{MnO}_{3}$ were successfully synthesized by a sol-gel Pechini method. The compounds were characterized with XRD, where single phase was observed for the pristine $\mathrm{Li}_{2} \mathrm{MnO}_{3}$. The XRD profile for $\mathrm{Li}_{1.5} \mathrm{Al}_{0.17} \mathrm{MnO}_{3}$, $\mathrm{Li}_{1.0} \mathrm{Al}_{0.33} \mathrm{MnO}_{3}$ and $\mathrm{Li}_{0.5} \mathrm{Al}_{0.5} \mathrm{MnO}_{3}$ indicated the presence of monoclinic/spinel phases, which was confirmed by Raman spectroscopy analysis and Neutron diffraction analysis. The spinel phase seems to form with increased aluminum substitution in the structure. X-ray photoelectron spectroscopy of $\mathrm{Mn} 2 \mathrm{p}$ orbital showed a decrease in binding energy for $\mathrm{Li}_{0.5} \mathrm{Al}_{0.5} \mathrm{MnO}_{3}$ and $\mathrm{Li}_{1.0} \mathrm{Al}_{0.33} \mathrm{MnO}_{3}$, while the change in binding energy for $\mathrm{Li}_{1.5} \mathrm{Al}_{0.17} \mathrm{MnO}_{3}$ was not significant. The shift to a lower binding energy for the samples indicates a decrease in the oxidation state of $\mathrm{Mn}$, leading to a better electrochemical performance. These interpretations were supported by charge/discharge study at a current density of $10 \mathrm{~mA} \mathrm{~g}^{-1}$, were an increase in capacity and better 
stability was observed for the $\mathrm{Li}_{0.5} \mathrm{Al}_{0.5} \mathrm{MnO}_{3}\left(70 \mathrm{mAh} \mathrm{g}{ }^{-1}\right)$ and $\mathrm{Li}_{1.0} \mathrm{Al}_{0.33} \mathrm{MnO}_{3}\left(62 \mathrm{mAh} \mathrm{g}^{-1}\right)$ compounds.

\section{Acknowledgements}

Financial Support from the NASA-CANM (Grant \# NNX08BA48A), NASA Space Grant (Grant \# NNX10AM80H) and the US Department of Energy (DOE) are acknowledged. We thank Dr. James Poston from the National Energy Technology Laboratory for his continual support with characterization measurements.. Financial and technical supports by Spallation Neutron Source user facility are sponsored by the Division of Scientific User Facilities, Office of Basic Energy Sciences, US Department of Energy, under contract DE-AC05-00OR22725 with UT-Battelle, LLC, are gratefully acknowledged. Support (MPP) for neutron characterizations was provided by Office of Science, Office of Basic Energy Sciences, Materials Sciences and Engineering Division, US Department of Energy. Fruitful discussions with Ms. María Abreu-Sepúlveda and Dr. Gurpreet Singh are also acknowledged

\section{$\underline{\text { References }}$}

[1] V. Etacheri, R. Marom, R. Elazari, G. Salitra, D. Aurbach, Challenges in the development of advanced Li-ion batteries: a review, Energy Environ. Sci. 4 (2011) 3243-3262.

[2] J. B. Goodenough, K.-S. Park, The Li-ion Rechargeable Battery: A Perspective, J. Am. Chem. Soc. (2013) 1167. 
[3] H. Tao, Z. Feng, H. Liu, X. Kan, P. Chen, Reality and Future of Rechargeable Lithium Batteries, The Open Mater. Sci. J. 5 (2011) 204-214.

[4] B. G. Pollet, I. Staffell, J.L. Shang, Current status of hybrid and fuel cell electric vehicles: From electrochemistry to market prospects, Electrochim. Acta 84 (2012) 235-249.

[5] J.H. Ryu, J. Eun, Y. Shin (2010), Cathode active material comprising mixture of lithium/manganese spinel oxide and lithium/nickel/cobalt/manganese oxide and lithium secondary battery containing same, US Patent No. 7,816,033 B2, Washington, DC: U.S. Patent and Trademark Office.

[6] A. J. Paterson, A. R. Armstrong, P. G. Bruce, Stoichiometric $\mathrm{LiMnO}_{2}$ with Layered Structure: Charge/Discharge Capacity and the Influence of Grinding, J. Electrochem. Soc 151 (2004) A1552-A1558.

[7] R. Wang , X. He , L. He, F. Wang, R. Xiao, L. Gu, H. Li, L. Chen, Atomic Structure of $\mathrm{Li}_{2} \mathrm{MnO}_{3}$ after Partial Delithiation and Re-Lithiation, Adv. Energy Mater. 3 (2013) 13581367.

[8] M.H. Rossouw, M.M. Thackeray, Lithium Manganese Oxides from $\mathrm{Li}_{2} \mathrm{MnO}_{3}$ for Rechargeable Lithium Battery Applications, Mat. Res. Bull. 26 (1991) 463-473.

[9] S. H. Park, Y. Sato, J.K. Kim, Y.S. Lee, Powder property and electrochemical characterization of $\mathrm{Li}_{2} \mathrm{MnO}_{3}$ material, Mater. Chem. Phys. 102 (2007) 225-230.

[10] N. Tran, L. Croguennec, M. Menetrier, F. Weill, P. Biensan, C. Jordy, C. Delmas, Mechanisms Associated with the "Plateau" Observed at High Voltage for the Overlithiated $\mathrm{Li}_{1.12}\left(\mathrm{Ni}_{0.425} \mathrm{Mn}_{0.425} \mathrm{Co}_{0.15}\right)_{0.88} \mathrm{O}_{2} \mathrm{System}$, Chem. Mater. 20 (2008) 4815-4825. 
[11] M. Sathiya, K. Ramesha, G. Rousse, D. Foix, D. Gonbeau, A.S. Prakash, M.L. Doublet, K. Hemalatha, J.-M. Tarascon, High Performance $\mathrm{Li}_{2} \mathrm{Ru}_{1-y} \mathrm{Mn}_{y} \mathrm{O}_{3} \quad(0.2<y<0.8)$ Cathode Materials for Rechargeable Lithium-ion Batteries: Their Understanding, Chem. Mater. 25 (2013) 1121-1131.

[12] D. Mori, H. Sakaebe, M. Shikano, H. Kojitani, K. Tatsumi, Y. Inaguma, Synthesis, phase relation and electrical and electrochemical properties of ruthenium-substituted $\mathrm{Li}_{2} \mathrm{MnO}_{3}$ as a novel cathode material, J. Power Sources 196 (2011) 6934-6938.

[13] Soo Kim, Jae-Kyo Noh, Seungho Yu, Wonyoung Chang, Kyung Yoon Chung and ByungWon Cho, Effects of transition metal doping and surface treatment to improve the electrochemical performance of $\mathrm{Li}_{2} \mathrm{MnO}_{3}$, J. Electroceram. 30 (2013) 159-165.

[14] S. Francis Amalraj, Daniel Sharon, Michael Talianker, Christian M. Julien, Luba Burlaka, Ronit Lavit, Ekaterina Zhecheva, Boris Markovsky, Ella Zinigrad, Daniela Kovacheva, Radostina Stoyanova, Doron Aurbach, Study of the nanosized $\mathrm{Li}_{2} \mathrm{MnO}_{3}$ : Electrochemical behavior, structure, magnetic properties, and vibrational modes, Electrochim. Acta 97 (2013) 259-270.

[15] Faxing Wang, Shiying Xiao, Minxia Li, Xiaowei Wang, Yusong Zhu, Yuping Wu, Akihiko Shirakawa and Jun Peng, A nanocomposite of $\mathrm{Li}_{2} \mathrm{MnO}_{3}$ coated by $\mathrm{FePO}_{4}$ as cathode material for lithium ion batteries, J. Power Sources 287 (2015) 416-421.

[16] Xin Dong, Youlong Xu, Lilong Xiong, Xiaofei Sun, Zhengwei Zhang, Sodium substitution for partial lithium to significantly enhance the cycling stability of $\mathrm{Li}_{2} \mathrm{MnO}_{3}$ cathode material, J. Power Sources 243 (2013) 78-87. 
[17] M.P. Pechini (1967), Method of preparing lead and alkaline earth titanates and niobates and coating method using the same to form a capacitor, Us Patent 3,330,697, Washington, DC: U.S. Patent and Trademark Office.

[18] J.F. Moulder, W.F. Stickle, P.E. Sobol, K.D. Bomben (1982), Handbook of X-ray Photoelectron Spectroscopy, Eden Prairie, MN, Physical Electronics, Inc

[19] N. Santander, S. R. Das, S. B. Majumder, R. S. Katiyar, Process optimization and electrochemical properties of lithium manganate cathode for rechargeable batteries, Surface and Coatings Technology 60 (2004) 177-178.

[20] P. Strobel, B. Lambert-Andron, Crystallographic and Magnetic Structure of $\mathrm{Li}_{2} \mathrm{MnO}_{3}, \mathrm{~J}$. Solid State Chem. 75 (1988) 90-98.

[21] T. Rao Penki, D. Shanmughasundaram, N. Munichandraiah, Polymer template-assisted microemulsion synthesis of large surface area, porous $\mathrm{Li}_{2} \mathrm{MnO}_{3}$ and its characterization as a positive electrode material of Li-ion cells, J. Solid State Electrochem. 17 (2013) 31253136.

[22] K. Kubobuchi, M. Mogi, H. Ikeno, I. Tanaka, H. Imai, T. Mizoguchi, Mn L2,3-edge X-ray absorption spectroscopic studies on charge-discharge mechanism of $\mathrm{Li}_{2} \mathrm{MnO}_{3}$, Appl. Phys. Lett. 104 (2014) 053906.

[23] S. F. Amalraj, L. Burlaka, C. M. Julien, A. Mauger, D. Kovacheva, M. Talianker, B. Markovsky, D. Aurbach, Phase transition in $\mathrm{Li}_{2} \mathrm{MnO}_{3}$ at various state of charge, Electrochemica Acta 123 (2014) 395-404. 
[24] C. Julien, Local cationic environment in lithium nickel-cobalt oxides used as cathode materials for lithium batteries, Solid State Ionics 136 (2000) 887-896.

[25] C. Julien, M, Massot, R. Baddour-Hadjean, S. Franger, S. Bach, J.P. Pereira-Ramos, Raman Spectra of birnessite manganese dioxides, Solid State Ionics 159 (2003) 345-356.

[26] D. Y.W. Yu, K. Yanagida, Structural Analysis of $\mathrm{Li}_{2} \mathrm{MnO}_{3}$ and Related Li-Mn-O Materials, J. Electrochem. Soc. 158(9) (2001) A1015-A1022.

[27] J. Preudhomme, P. Tarte, Infrared studies of spinels-II The experimental bases for solving the assignment problem, Spectrochim. Acta 27A (1971) 845-851.

[28] D. Y. W. Yu, K. Yanagida, Y. Kato, H. Nakamura, Electrochemical Activities in $\mathrm{Li}_{2} \mathrm{MnO}_{3}$, J. Electrochem. Soc. 156 (6) (2009) A417-A424.

[29] S. F. Amalraj, B. Markovsky, D. Sharon, M. Talianker, E. Zinigard, R. Persky, O. Haik, J. Grinblat, J. Lampert, M. Schulz-Dobrick, A. Garsuch, L.99 Burlaka, D. Aurbach, Study of the electrochemical behavior of the "inactive" $\mathrm{Li}_{2} \mathrm{MnO}_{3}$, Electrochem. Acta 78 (2012) 3239

[30] J. Gim, J. Song, H. Park, J. Kang, K. Kim, V. Mathew, J. Kim, Synthesis and characterization of integrated layered nanocomposites for lithium ion batteries, Nanoscale Res. Lett. 7:60 (2012) 1-9. 